\title{
CORRESPONDENCE
}

Correspondents are asked to be brief

Advice in the M.D.U.'s Annual Report

H. Milnes Walker, F.R.C.S. . . . . . . 168

Acute Renal Failure

K. E. Britton, M.R.C.P., and others. . . . . 168

Drugs in Ceylon

G. Teeling-Smith, B.A........... 168

Epitaph for the M.C.H.C.

M. S. Rose, M.B., PH.D....... . . . . . 169

Shortage of Physiotherapists

R. S. Savidge, F.R.C.P... . . . . . . . 169

Neuropathy after Clioquinol

L. M. McEwen, B.M. . . . . . . . . . . . . . 169
Better Specimens from the Female Genital

Tract

S. Selwyn, M.D., and J. K. Oates, F.R.C.P.ED. .170

Verdict on CS

G. R. N. Jones, M.A., PH.D. . . . . . . . 170

Epidemiology of Malaria

L. J. Bruce-Chwatt, M.D., D.T.M.\&H. . . . . . 170

Drugs and the Fetal Heart Rate

J. de Haan, M.D. and L. A. M. Stolte, M.D...171

Doctor in the Lab

G. A. C. Summers, F.R.C.PATH. . . . . . . 171

F.D.P. in Glomerulonephritis

F. E. Preston, M.D., and others
Treatment of Myocardial Infarction

A. P. Fletcher, M.D. . . . . . . . . . . . 172

The Gut and Dermatitis Herpetiformis

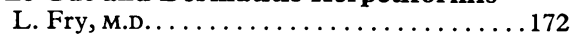

Congenital Leukaemia and Mongolism

Margaret D. Baber, M.D., D.C.H......... 172

Wegener's Granulomatosis

R. M. Sykes, M.B. . . . . . . . . . . . . . 173

Halothane Hepatitis

B. R. J. Simpson, F.F.A. R.C.S., and L. Strunin,

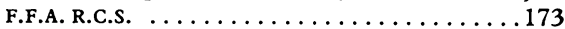

Non-specific Backache

J. H. Cyriax, M.D....

\section{Advice in the M.D.U.'s Annual Report}

SIR,-On page 16 the Annual Report of the Medical Defence Union ${ }^{1}$ gives advice to its members, in dealing with cases of suspected appendicitis, which can, colloquially, be summarized: When in doubt, take it out.

While this may well be wise advice in this country, it could be disastrous in other lands where the pattern of disease differs from that to which we in Britain are accustomed. In West Africa, and, I suspect, in many other parts of the tropics, the association of sudden abdominal pain, tenderness, and diarrhoea is far more likely to herald an acute attack of dysentery than one of appendicitis. This is a well-known pitfall for the surgeon newly arrived in the tropics, where appendicitis is relatively rare. Laparotomy under such circumstances is the worst possible treatment and may well lead to a fatal result.-I am, etc.,

Crewe, Cheshire

H. Milnes WALKER

1 The Medical Defence Union, Annual Report. 1971.

\section{Acute Renal Failure}

SIR,-While agreeing with Mr. M. E. Mayo and others (28 August, p. 516) that the results of renography should be interpreted with caution in patients with acute oliguria, it may be helpful briefly to indicate how to be cautious and what the limitations of standard renography are in this context.

The third phase is a record of the amount remaining behind in the kidney at any time. Equating absence of the third phase of the renogram with obstruction and talk of the "obstructed" renogram is a throwback to the time when the third phase was called the "excretory" phase on the idea that it was solely related to the amount of hippuran leaving the kidney. In acute renal failure, while the amount of hippuran taken up by the kidney continues to exceed the amount leaving the field of view of the kidney region detector, the renogram will continue to rise.

The differentiation of the pattern obtained in acute renal failure from that in bilateral obstructive nephropathy depends on the equality or otherwise of the ability of the kidneys to take up hippuran. Acute renal failure usually affects the pair of kidneys equally and symmetry of ${ }^{131} \mathrm{I}$ hippuran uptake occurs. In bilateral obstructive nephropathy one kidney is usually affected before the other and asymmetry of ${ }^{131}$ I hippuran uptake by the pair of kidneys is found. ${ }^{1}$ This is the clinical limitation of the test. The technical limitation is due to the fact that the uptake of ${ }^{131}$ I hippuran by the kidneys is not re- flected by the standard renogram when renal function is poor. In this circumstance the contribution to the composite renogram of ${ }^{131}$ I hippuran in non-renal tissue in the environment of the kidney is greater than the contribution of ${ }^{131} \mathrm{I}$ hippuran in that kidney. Since the contribution by the renal environment is usually greater on the right side than the left (mean ratio $1 \cdot 1$ to 1 , scatter \pm 0.4 , one standard deviation), there is a tendency for asymmetry of a pair of renograms when the hippuran uptake by each kidney is, in fact, symmetrical (Figs. 2, 3, and 5 of $\mathrm{Mr}$. Mayo and others). In obstructive nephropathy the asymmetry of hippuran uptake by the pair of kidneys may not be obvious in the standard renogram owing to the effect of the contribution of 131I hippuran in the renal environments (Fig. 1 of $\mathrm{Mr}$. Mayo and others).

Renography will continue to give misleading results in patients with poor renal function if no attempt is made to correct the composite renograms for the large distortions that result from the renal environment. The method of computer-assisted blood background subtraction (CABBS) $^{2}$ is no longer sophisticated but straightforward. With the help of the Department of Health and Social Security a mobile apparatus has been designed, built, ${ }^{3}$ and tested. ${ }^{45}$ Using this system, the production of "kidney curves," renograms corrected for the contributions of the renal environments, is simple and automatic. Kidney curves may be obtained in the ward from patients with acute oliguria, who are often seriously ill.

The use of the hippuran output curve ${ }^{5-7}$ may be of further help in the differential diagnosis of acute oliguria.-We are, etc.,

St. Mary's Hospital,

K. E. Britton

London W. 2

M. M. BLUHM N. J. G. Brown

Middlesex Hospital

1 Joekes, A. M., and Rellan, D. R., Lancet, 1965 , 2, 96.

2 Britton, K. E., and Brown, N. J. G., British Fournal of Radiology, 1968, 41, 570 .

3 Nuclear Enterprises Ltd., Edinburgh.

4 Britton, K. E., and Brown, N. J. G., in Computers in Radiology, International Meeting, Brussels, 1969, ed. R. de Haene and A. Wambersie, Basle, Karger, 1970.

Britton, K. E., and Brown, N. J. G., Clinical 6 Renography, Lloyd-Luke Ltd., London, 1971, Symposium, International Atomic Rotterdam Agency, Vienna, 1970.

7 Britton, K. E., and Brown, N. J. G., Proceedings

of the Royal Society of Medicine, 1970, 63.
1246.

\section{Drugs in Ceylon}

SIR,-Y Your leading article (25 September, p. 724) has drawn attention to some of the diffculties and dangers underlying Professor S. Bibile and Dr. S. A. Wickremasinghe's proposals for the supply of pharmaceuticals in Ceylon. One could go further and question whether they had interpreted their terms of reference sufficiently widely in relation to the adverse balance of trade in their country. They looked at the problem in the narrow sense of how to cut down the drug bill so as to reduce imports. The other question to which they could have addressed themselves was "How could the pharmaceutical industry contribute to the economy of Ceylon?" Had they done so, their recommendations would all have been reversed. They would have been concerned with creating an economic climate in Ceylon which would encourage British, Swiss, or U.S. pharmaceutical firms, for example, to undertake or extend their local manufacture so as to export from the 